\title{
DOI https://doi.org/10.30525/978-9934-26-116-9-46
}

\section{МЕТОДИ ТЛУМАЧЕННЯ, ЗАСТОСОВНІ В РІШЕННЯХ СУДУ СС}

\author{
Камінська I. B. \\ докторант відділу теорії держави і права \\ Інституту держави і права імені В. М. Корецького \\ Національної академії наук України \\ м. Київ, Украӥна
}

В науковій літературі існує сталий підхід до визначення поняття «тлумачення норм права», під яким розуміють: інтелектуальну діяльність, спрямовану на визначення дійсного змісту норми права або його роз'яснення, з метою правильного іiї застосування та реалізації [1]. Подібні за змістом визначення можна знайти у наукових працях П. М. Рабіновича,[2] М. І. Козюри,[3] О. В. Зайчука, Н. М. Оніщенко [4] та інших. Питання переліку методів тлумачення норм права не нове для правової герменевтики, проте актуальне в світлі дослідження сучасних методів тлумачення, які використовують не лише національні судові органи, а й міжнародні судові інституції, зокрема Суд Свропейського Союзу (надалі - Суд СС).

Досягнення визначених в статті 1 Угоди про асоціацію між Україною, з однієї сторони, та Європейським Союзом, Європейським співтовариством 3 атомної енергії і їхніми державами-членами, 3 іншої сторони (надалі - Угода про асоціацію), цілей, передбачає проведення системних реформ, в тому числі через поступову адаптацію законодавства України до асquis ЄС та їх ефективну реалізацію. Апроксимація інтеграційних норм права - процес непростий, що пов'язано зі складністю текстів вторинного законодавства СС та необхідністю розуміння їх змісту у взаємозв'язку з положеннями Договору про ЄС та Договору про функціонування ЄС. Такі висновки підтверджуються значною кількістю попередніх рішень Суду $\mathrm{CC}$, винесених в порядку статті 267 Договору про функціонування СС, відповідно до якої Суд Європейського Союзу на запит суду держави-члена має юрисдикцію виносити попередні рішення стосовно: тлумачення Договорів; чинності та тлумачення актів установ, органів, служб та агенцій Союзу [5]. Такі запити національні суди направляють у разі, якщо без отримання такого тлумачення вони не можуть прийняти рішення керуючись право ЄC. 
Судова практика Суду $С \mathrm{C} є$ найкращим джерелом тлумачення та інтерпретації норм права СС у конкретних обставинах його застосування, вивчення якої є необхідною передумовою розуміння основної ідеї інтеграційного правового порядку та іiі ефективного відтворення у національному правопорядку. В теорії права зазвичай питання тлумачення норм права подано через визначення поняття, об'єкту, суб'єктів, видів та методів тлумачення, зміст яких визначений через призму національної правової системи, однак, в умовах реалізації інтеграційного права та тісної взаємодії національних інституцій та інституцій ЄC, зміст таких положень слід доповнити особливостями, притаманними інтеграційному порядку. А тому, дослідження судової практики Суду СС на предмет застосованих у них методів тлумачення $\epsilon$ частиною доктрини правового тлумачення.

Тлумачення норм права передбачає використання певного інструментарію, який забезпечує істинність відтворення змісту норми. Таким інструментарієм є методи тлумачення, серед яких, традиційно виділяють: філологічний, системний, історичний, цільовий, функціональний, історико-політичний, теологічний, логічний. Такі методи традиційно використовують національні судові органи, надаючи тлумачення господарським, цивільним, адміністративним нормам права. Зазначені методи використовує й Суд $\mathrm{CC}$, проте 3 притаманними йому особливостями, які пов'язані з необхідністю поєднати правові погляди суддів і генеральних адвокатів, призначених до суду з різних правових систем. Віднайдений ними консенсус у підходах до тлумачення норм інтеграційного права сприяв формуванню єдиної судової доктрини тлумачення норм права, спільної для континентальної та загальної правової системи.

В європейській правовій спільноті питання застосованих Судом СС методів тлумачення цікавило юристів та науковців 3 самих перших років його функціонування. Так, 27-28 вересня 1976 року в м. Люксембург було проведено масштабну конференцію, присвячену цій проблематиці, спікерами на якій виступили судді Суду ЄС та генеральні адвокати 3 широким колом учасників від національних судових органів держав-членів. Мета цієї конференції полягала в обговоренні конкретних рішень Суду СС на предмет застосованих у них методів тлумачення та визначення, чи є такі методи вірними та чи не сприяють вони визначенню дійсного змісту норм інтеграційного права [6].

Особливості методів тлумачення застосовані у перших рішеннях Суду ЄС розкрили у своїх наукових працях Г. Бебр, Х. Кутчер, Г. Гамсон, Д. Меерш, Н. Расмумен, які виокремлювали такі основні 
методи: буквальний чи екзегетичний, історичний, порівняльний, схематичний та телеологічний методи, вказуючи на те, що частіше Суд СС застосовував схематичний і теологічний метод. Пояснюючи це тим, що інтеграційне право зароджувалось і його тлумачення було можливе лише 3 позиції цілей та взаємозв'язку норм. Станом на сьогодні, правова система СС набула довершеної форми, в тому числі завдяки судовій доктрині. Проте кількість запитів на тлумачення норм права постійно зростає, оскільки відбувається еволюція вторинного законодавства, тлумачення якого зачасти потребує застосування одразу декількох методів тлумачення з дотриманням певної послідовності у пошуках реального змісту норми права, виключаючи можливість неповного тлумачення.

Для аналізу способів тлумачення, які використовує Суд СС, нами було обрано ряд рішень, прийнятих ним після набрання чинності Лісабонської угоди (умовно з 2010 року по теперішній час), що обумовлено появою у текстах договорів положень про права, свободи та принципи, закладені в Хартії основоположних прав Європейського Союзу та приєднанням до Європейської Конвенції про захист прав людини і основоположних свобод.

На підставі аналізу практики Суду СС пропонується виокремити такі методи тлумачення:

1) порівняльно-лінгвістичний метод - застосовується в ситуаціях диспропорції різних мовних текстів нормативних актів та передбачає, що основою для тлумачення норми мають бути тексти на всіх офіційних мовах [7];

2) метод жорсткого тлумачення - застосовується до перехідних та виняткових положень законодавства [8; 9];

3) тлумачення норм через призму загальних прав [10;11];

4) застосування за аналогією [12];

5) комплексний метод тлумачення, який передбачає одночасність застосування декількох методів, зокрема: буквального, системного, історичного та телеологічного тлумачення [13];

6) автономне тлумачення термінів - якщо в тексті законодавства ЄС не визначено поняття, яке в ньому застосовується і відсутнє посилання на національне законодавство, то суд надає власне визначення поняття [14];

7) теологічний метод - тлумачення через врахування загальної мети та цілей нормативного акту; [15]

8) ієрархічний метод тлумачення - вторинні акти законодавства ЄС повинні тлумачитися, наскільки це можливо, відповідно до основного акту; 
9) історичний метод - через простеження еволюції нормативного регулювання;

10) раціональний метод тлумачення - через оцінку загальних економічних показників та обставин, які сприяли прийняттю нормативного акта;

11) метод обмежувального тлумачення;

12) метод широкого тлумачення та інші.

Окремі традиційні методи так і продовжують застосовуватися Судом СС, адже вони складають основу тлумачення норм права, але поряд з ними виникає потреба пошуку застосування більш широкого інструментарію.

Отже, проаналізувавши ряд рішень Суду ЄС можна зробити висновок, що судова практика сформувала доктрину методів тлумачення норм інтеграційного права, яка поєднує в собі традиційні підходи до тлумачення, притаманні континентальній правовій системі та загальній, та специфічні - характерні інтеграційному правопорядку. Дослідження методів тлумачення, застосовних Судом СС, - є складовою правової герменевтики, а їх результати можна використовувати, як при вивченні європейського права, так і теорії держави і права, враховуючи тенденцію вступу України в СС та тісного взаємозв'язку національних органів влади та інституцій $Є С$.

\section{Література:}

1. Загальна теорія держави i права: [Підручник для студентів юридичних вищих навчальних закладів] / М. В. Цвік, О. В. Петришин, Л. В. Авраменко та ін.; За ред. д-ра юрид. наук, проф., акад. АПрН України М. В. Цвіка, д-ра юрид. наук, проф., акад. АПрН України О. В. Петришина. - Харків: Право, 2009. - С. 419-420. 584 с.

2. П. М. Рабінович Основи теорії та філософії права: навч. посібник. Львів : Видавництво ЛОБФ «Медицина і право», 2021. С. 196. 256 с.

3. Загальна теорія права: Підручник / За заг. ред. М.І. Козюбри. - К.: Baiтe, 2015. - 392 c.

4. Теорія держави i права. Академічний курс: Підручник / За ред. О. В. Зайчука, Н. М. Оніщенко. - К.: Юрінком Інтер, 2006. C. $468-469.688 \mathrm{c}$.

5. Консолідовані версії Договору про Європейський союз та Договору про функціонування Європейського Союзу [Електронний pecypc]. - Режим доступу : https://zakon.rada.gov.ua/laws/show/994_b06

6. Methods of interpretation as seen by a judge at the Court of Justice. Judicial and Academic Conference, 27-28 September 1976. Luxemburg, 1976. P. 13-30. 
7. Case T-61/13: Research and Production Company "Melt Water" UAB contre Office de l'harmonisation dans le marché intérieur (marques, dessins et modèles) (OHMI), T 61/13, ECLI:EU:T:2014:265 (p. 28)

8. Case F-29/05: Jean-François Vivier v European Commission, F-29/05, ECLI:EU:F:2010:114 (p. 67-70)

9. Case F-107/05: Gergely Toth v European Commission, F-107/05, ECLI: EU:F:2010:118 (p. 71-74)

10. Case C-394/12: Shamso Abdullahi v Bundesasylamt, C-394/12, ECLI:EU: C:2013:813 ( p. 51, 62

11. Case C-583/11: P Inuit Tapiriit Kanatami e.a. v European Parliament, Council of the European Union, C-583/11 P, ECLI:EU:C:2013:625 (p. 50)

12. Case F-81/09: Luigi Marcuccio v European Commission, F-81/09, ECLI:EU:F:2011:13 (p.55)

13. Case T-124/14: Republic of Finland v European Commission, T-124/14, ECLI:EU:T:2015:955 (p.24)

14. Case T-62/10 P: Brigitte Zangerl-Posselt v European Commission, T-62/10 P, ECLI:EU:T:2011:463 (p. 41, 43)

15. Case C-420/1: Maksu- ja Tolliamet v Heavyinstall OÜ,C-420/19, ECLI:EU:C:2021:33 (cf. point 27)

DOI https://doi.org/10.30525/978-9934-26-116-9-47

\section{ШЛЯХИ ВДОСКОНАЛЕННЯ АДМІНІСТРАТИВНО- ПРАВОВОГО ЗАБЕЗПЕЧЕННЯ ЗАПРОВАДЖЕННЯ МІЖНАРОДНИХ СТАНДАРТІВ У СФЕРІ ЗАХИСТУ ПРАВ ЛЮДИНИ В УМОВАХ СВРОПЕЙСЬКОЇ ІНТЕГРАЦІЇ УКРАЇНИ}

Криворучко Л. С.

доктор юридичних наук, адвокат

м. Київ, Україна

Шлях України до європейської спільноти передбачає впровадження нормативно-правового забезпечення та захист затверджених прав людини на основі принципів сучасного демократичного міжнародного права, створення правової, соціальної та демократичної країни відповідно до міжнародних стандартів країни, яка посяде гідне місце у світовому співтоваристві. Зазначені стандарти існують на загальноєвропейському рівні, подолали тернистий шлях становлення 